\title{
Considerații privind aplicarea normelor de etică în activitatea didactică universitară ${ }^{1}$
}

\author{
Angela Stela IVAN1, Elisabeta SLABU ${ }^{1, *}$
}

1 Universitatea „Dunărea de Jos” din Galați; angela.ivan@ugal.ro; elisabeta.slabu@ugal.ro

* Correspondence: elisabeta.slabu@ugal.ro

Citation: Ivan, A.S. \& Slabu, E. (2021) Considerații privind aplicarea normelor de etică în activitatea didactică universitară. Revista Etică și Deontologie. 1(1), 18-24

https://doi.org/10.52744/RED.2021.01.03

Publisher's Note: RED stays neutral with regard to jurisdictional claims in published maps and institutional affiliations.

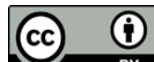

Copyright: (C) 2021 by the authors. Submitted for possible open access publication under the terms and conditions of the Creative Commons Attribution (CC BY) license

(https://creativecommons.org/ licenses/by/4.0/).
Rezumat: Activitatea didactică universitară are la bază un sistem de valori etice unanim recunoscute, care gestionează și orientează comportamentul membrilor comunităţii academice. Aceste valori sunt încorporate într-o serie de reguli și norme de comportament pe care le regăsim în legi și în acte administrative normative denumite Coduri de etică și deontologie universitară, avizate prin deciziile Senatelor universitare şi care fac parte integrantă din Cartele universitare. Constituie o sarcină și o preocupare permanentă a membrilor Comisiilor de etică universitară, să stabilească forţa juridică a acestor coduri şi relaţiile lor cu celelalte reglementări normative aprobate de către aceleași foruri din conducerea universitară. Atunci când se evaluează dacă un membru al comunității universitare a respectat sau nu normele de etică academică, în Comisiile de etică se analizează mai multe acte juridice ce pot fi aplicate cauzei care se discută. Care este procedura prin care se stabilește ce act administrativ va sta la baza deciziei ce va fi luată? Unele acte administrative normative au o forță juridică mai mare decât a altora? Sau toate au aceeaşi forță juridică? Vom afla analizând multitudinea de reglementări juridice care au relevanţă în soluţionarea cauzelor cu care sunt sesizate Comisiile de etică universitară.

Cuvinte cheie: Codul de etică şi deontologie universitară, Comisia de etică universitară, act administrativ normativ.

\footnotetext{
${ }^{1}$ Articol prezentat în cadrul Conferinței Internaționale Valorile Etice în Societatea Actuală - VESA 2021 (3-5 iunie).
} 


\section{Valorile etice universitare}

Înțeleasă ca „centru de cultură, de cunoaştere, de cercetare” (Magna Charta Universitatum, 1988, p. 1), „universitatea nu îşi poate îndeplini misiunea - aceea de a servi umanitatea - în afara cadrului etic" (Jeder, 2018, p. 65).

În perioada actuală, exigențele de natură etică se impun din ce în ce mai mult, în toate domeniile. $\mathrm{Cu}$ atât mai mult, în educație, valorile etice trebuie promovate şi respectate de către toți membrii comunității, fie ei elevi, studenți, profesori sau alte categorii de persoane implicate în activitatea educativă.

Etica şi integritatea academică sunt strâns legate de un anumit set de valori. Potrivit doamnei Elena Emilia Ştefan (2018, p. 65), „sistemul de valori etice universitare constituie cadrul de formalizare a regulilor consensuale morale şi de integritate în domeniul academic, expresie a poziţiilor definitorii faţă de ceea ce este permis sau nu în mediul universitar." Valorice etice orientează activitatea în domeniul învățământului superior, în general, precum şi în interiorul mediului academic şi al comunității universitare. Acestea definesc relațiile moral-profesionale dintre membrii comunității universitare, între aceştia şi colaboratorii externi, inclusiv cu membrii echipelor de evaluare instituțională pentru clasificarea universităților." (Ştefan, 2018, p. 65).

Valorile etice universitare sunt următoarele:

$\checkmark$ libertatea academică, autonomia personală;

$\checkmark$ transparenţa,

$\checkmark$ etica relaţiilor între membrii comunităţii academice;

$\checkmark$ respectul, grija şi toleranţa;

$\checkmark$ dreptatea şi echitatea;

$\checkmark$ profesionalismul;

$\checkmark$ primatul meritocraţiei;

$\checkmark$ responsabilitatea profesională şi socială.

Regăsim aceste valori menționate pe larg în Metodologia de etică şi integritate în procesul de evaluare a universităţilor din România, elaborată în cadrul proiectului „Pregătiți pentru a inova, pregătiți pentru a răspunde mai bine nevoilor locale. Calitate şi diversitate a universităților din România" implementat de Unitatea Executivă pentru Finanțarea Învățământului Superior, Cercetare, Dezvoltare şi Inovare, în parteneriat cu Asociaţia pentru Implementarea Democrației şi European University Association (Metodologia, 2013).

Aşadar, evaluarea universităților nu presupune doar evaluarea calității activităţilor desfăşurate pe plan didactic şi de cercetare, ci şi evaluarea modului în care sunt respectate normele de etică şi integritate de către profesioniștii din unitățile de învățământ superior. Întreaga activitatea care se realizează în cadrul universitar este evaluată atât din punct de vedere al cercetării, al activității didactice cât şi din punct de vedere etic. 
În opinia doamnei Daniela Jeder, „interiorizarea valorilor este un proces complex și de durată pentru care este nevoie de perseverență, consecvență, credință şi optimism. Explorarea spațiului valorilor, alături de preocuparea pentru realizarea și implementarea unei educații etice la nivel universitar este un prim pas pentru eliminarea vulnerabilităților din spațiul academic, pentru schimbarea mentalităților, pentru construirea de repere pentru normalitate şi, credem, un sprijin pentru evoluția morală la nivel social." (Jeder, 2018, p. 103-104).

2. Încorporarea normelor de etică în documentele cu caracter normativ aprobate de conducerea universităţilor

Art. 2 din Legea nr. 1/2011 a educaţiei naţionale (Lege, 2011) stabileşte în alin. (3) următoarele: „Idealul educațional al şcolii românești constă în dezvoltarea liberă, integrală şi armonioasă a individualității umane, în formarea personalității autonome şi în asumarea unui sistem de valori care sunt necesare pentru împlinirea şi dezvoltarea personală, pentru dezvoltarea spiritului antreprenorial, pentru participarea cetățenească activă în societate, pentru incluziune socială şi pentru angajare pe piaţa muncii."

Art. 4 lit. f) din aceeaşi lege arată că „Educația şi formarea profesională a copiilor, a tinerilor şi a adulților au ca finalitate principală formarea competențelor, înțelese ca ansamblu multifuncțional şi transferabil de cunoștințe, deprinderi/abilități şi aptitudini, necesare pentru... cultivarea sensibilităţii faţă de problematica umană, faţă de valorile moral-civice şi a respectului pentru natură şi mediul înconjurător natural, social şi cultural”.

În România, fiecare universitate are aprobat un cod de etică, iar din 2018, în baza Ordinului Ministerului Educației Naționale nr. 3131/2018, programele de studii de masterat şi doctorat includ obligatoriu cursuri de etică şi integritate academică, iar programele de studii de licență pot avea, opțional, astfel de cursuri (Ordin, 2018).

Valentin Mureşan (2009, p. 102) ne oferă o definiție a codului de etică, astfel: „un ansamblu coerent de valori, principii şi norme morale, impuse sau nu prin sancțiuni punitive de instituție, pentru asigurarea unei vieți sociale şi profesionale reuşite, integre, pentru sporirea bunăstării membrilor ei, a instituției ca atare şi a societății în sens larg, pentru diminuarea sau eliminarea oricăror vătămări ce ar putea fi aduse membrilor instituției, pentru respectarea demnității, integrităţii şi autonomiei tuturor celor afectați de activitățile instituției şi pentru asigurarea unor protecții egale, imparțiale, a tuturor membrilor instituției în raporturile reciproce şi în raporturile acestora cu societatea în ansamblu" .

Codurile de etică aprobate de către universități sunt structurate pe un set de valori, principii şi norme morale, care trebuie cunoscute şi respectate de către toți membrii comunității. Se subliniază importanța conceptului de responsabilitate a membrilor comunității academice cu privire la programele de studii, cercetări, conduită şi se propun sancțiuni în caz de denigrare, calomnii, răspândirea unor informații false etc.

Prin codurile de etică universitățile urmăresc „promovarea integrității academice, respectarea normelor de etică profesională/deontologice, concentrându-se 
pe conştientizarea comunității academice cu privire la valorile, normele şi principiile etice promovate de instituție, pe activități de prevenție și combatere a comportamentelor ne-etice ce pot apărea atât în activitățile de cercetare, cât şi în cele ale actului educativ" (Jeder, 2018, p. 87).

3. Analiza actelor cu caracter normativ aprobate în cadrul Universităţii Dunărea de Jos din Galaţi, ce conţin reglementări privind etica academică

Carta Universităţii Dunărea de Jos din Galaţi (Carta, 2012) stabileşte că: „Răspunderea publică implică obligaţia universităţii sub următoarele aspecte:

a) respectarea legislației în vigoare, a cartei proprii, a politicilor naţionale şi europene în domeniul învățământului superior;

b) aplicarea reglementărilor în vigoare referitoare la asigurarea şi evaluarea calităţii în învățământul superior;

c) respectarea politicilor de echitate şi etică universitară cuprinse în Codul de etică şi deontologie profesională universitară, aprobat de Senatul universitar, parte integrantă a prezentei..."

\section{Aceeași Cartă specifică următoarele:}

- autonomia universitară se realizează prin... asigurarea unei bune conduite în cercetarea ştiinţifică şi activitatea universitară...

- drepturile şi îndatoririle membrilor comunității universitare sunt stabilite prin reglementările legale în vigoare şi prin reglementările universitare (Carta universitară, Codul de etică universitară, contractul individual de muncă).

- personalul didactic şi de cercetare, personalul didactic şi de cercetare auxiliar, precum şi cel de conducere, de îndrumare şi de control din învățământul superior răspunde disciplinar pentru încălcarea îndatoririlor ce îi revin potrivit contractului individual de muncă, precum şi pentru încălcarea normelor etice sau de comportare care dăunează interesului învățământului şi prestigiului universităţii. Se interzice ocuparea posturilor didactice şi de cercetare de către persoane la care s-a dovedit, conform legii, că au avut abateri grave de la buna conduită în cercetarea ştiințifică şi activitatea universitară.

- prevederile Cartei sunt completate de celelalte reglementări universitare: coduri, regulamente, metodologii, norme aprobate de Senatul Universității.

- studenții au cel puțin un reprezentant în comisiile de etică, de asigurare a calității, precum şi în alte comisii cu caracter social.

- Comisia de etică a Senatului propune acestuia soluții în cazurile de litigii între cadre didactice, sau între studenți şi cadre didactice, sau în situațiile de încălcare a eticii universitare.

Codul de etică şi deontologie profesională universitară al UDJ Galaţi (Cod, 2011) reglementează conduita membrilor comunității academice din 
STICA
ȘIONTOLOGIE Angela Stela IVAN * Elisabeta SLABU

Universitatea „Dunărea de Jos” din Galați, funcționează ca un contract moral între membrii comunității universitare şi universitate, este obligatoriu pentru toți membrii comunității academice și promovează următoarele valori: dreptatea, echitatea, egalitatea de şanse, demnitatea, libertatea individuală şi academică, proprietatea intelectuală, integritatea profesională şi morală, cinstea, onestitatea, corectitudinea, datoria, responsabilitatea publică.

Comisia de etică universitară a UDJ Galați are următoarele atribuții, aprobate prin Regulamentul de organizare şi funcţionare (Regulament, 2013):

a) cercetează şi soluţionează abaterile de la etica universitară, pe baza sesizărilor sau prin autosesizare;

b) realizează un raport anual referitor la situația respectării eticii și deontologiei profesionale universitare şi a eticii activităților de cercetare. Raportul se prezintă rectorului, senatului universitar şi constituie un document public;

c) contribuie la elaborarea Codului de etică şi deontologie profesională universitară. Codul este supus aprobării senatului universitar, iar după aprobare este inclus în Carta universitară;

d) exercită atribuțiile cuprinse în Legea nr. 206/2004, cu modificările şi completările ulterioare;

e) exercită alte atribuții prevăzute de lege sau stabilite în Carta universitară.

Personalul didactic şi de cercetare, personalul didactic şi de cercetare auxiliar, precum şi cel de conducere, de îndrumare şi de control din învățământul superior răspunde disciplinar pentru încălcarea îndatoririlor ce îi revin potrivit contractului individual de muncă, precum şi pentru încălcarea normelor de comportare care dăunează interesului învăţământului şi prestigiului unităţii/instituţiei.

Regulamentul activităţii universitare a studenţilor (Regulament, 2017) din cadrul UDJ Galați prevede faptul că studenţii trebuie să respecte Codul de etică şi deontologie profesională universitară al UDJ Galaţi, iar nerespectarea acestor prevederi atrage aplicarea de sancţiuni, aşa cum sunt stabilite în Regulament.

Aşadar, multe din documentele cu caracter normativ elaborate şi aprobate în cadrul UDJ Galați conţin prevederi privind necesitatea respectării normelor de etică şi integritate academică, fiind stabilite şi sancțiuni pentru situațiile în care aceste norme sunt încălcate. Sunt stabilite şi organismele interne care verifică modul în are sunt respectate normele de etică şi integritate academică, respectiv Comisia de etică universitară a UDJ, şi organismul la care poate fi contestată hotărârea luată de Comisia de etică - Senatul UDJ Galaţi. Comisia juridică şi de etică a Senatului UDJ examinează documentele care au stat la baza luării deciziei de către Comisia de etică a UDJ Galați şi propune Senatului UDJ aprobarea / respingerea contestației depusă de persoana nemulțumită. Decizia Senatului este definitivă şi poate fi atacată în instanță.

Apar însă întrebările următoare: decizia luată de Senatul universitar poate avea ca bază legală nu Codul de etică ci un al act cu caracter normativ aprobat tot de către Senat, pe care Comisia juridică şi de etică a Senatului îl consideră incident în cauza supusă cercetării? Încălcarea normelor de etică universitară reprezintă sau nu o 
abatere disciplinară? Care sunt normele legale utilizate la individualizarea sancțiunii: Codul muncii sau Legea educației naționale?

Din conținutul Cartei UDJ reiese că documentul intitulat Cod de etică şi deontologie universitară este parte componentă a acesteia. Acest lucru presupune şi o supraordonare asupra unor acte cu caracter normativ elaborate şi aprobate la nivelul UDJ Galați, cum ar fi regulamentele, procedurile şi metodologiile, care nu conțin mențiunea că sunt parte componentă a Cartei.

Dar dacă în cauza cercetată sunt incidente prevederile mai multor astfel de acte cu caracter normativ, cu aceeași forță juridică, într-un caz cercetat de Comisia de etică se analizează şi se aplică cu prioritate normele Codului de etică? Sau se aplică normelor altor regulamente aprobate la nivelul UDJ Galați?

Într-o astfel de situație considerăm că deciziile luate de către Comisia de etică trebuie să fie argumentate legal utilizând prevederile Codului de etică, nu ale altor regulamente şi metodologii sau proceduri care sunt aprobate de acelaşi organ de conducere a universității. Eventual se poate acționa, dar nu de către Comisia de etică, ci de către structurile de conducere ale facultăților, prin sesizarea unei comisii de cercetare disciplinară, care să cerceteze dacă faptele săvârşite reprezintă încălcări ale prevederilor cu caracter normativ aprobate la nivelul universității şi dacă trebuie sancționate.

Iar în ceea ce priveşte stabilirea sancțiunii în cazul constatării încălcării normelor de etică, trebuie precizat că în conținutul Codului de etică au fost preluate prevederile art. 312 alin. (2) din Legea educației naționale: „Sancțiunile disciplinare care se pot aplica personalului didactic şi de cercetare sunt următoarele:

a) avertisment scris;

b) diminuarea salariului de bază, cumulat, când este cazul, cu indemnizația de conducere, de îndrumare şi de control;

c) suspendarea, pe o perioadă determinată de timp, a dreptului de înscriere la un concurs pentru ocuparea unei funcții didactice superioare ori a unei funcții de conducere, de îndrumare şi de control, ca membru în comisii de doctorat, de master sau de licență;

d) destituirea din funcția de conducere din învățământ; e)desfacerea disciplinară a contractului de muncă" (Lege, 2011).

Aceste sancțiuni, deoarece nu sunt bine determinate, lipsind limitele minime şi maxime pentru literele b) şi c), trebuie individualizate în funcție de gravitatea faptelor săvârşite. Aceasta presupune apelarea la prevederile Codului muncii, pentru a se respecta principiile echității și predictibilității normelor juridice.

\section{Concluzii}

Adoptarea unui Cod de etică la nivelul universităților presupune şi responsabilizarea membrilor comunității academice şi conştientizarea faptului că încălcarea normelor lui presupune suportarea consecințelor specifice. Sancțiunile vor fi aplicate numai după o atentă analiză atât a faptelor cât şi a prevederilor legale incidente, cu o justă individualizare. Chiar ar trebui ca în conținutul Codului să fie 
stabilite anumite limite ale sancțiunilor ce pot fi aplicate, astfel încât să fie păstrat un echilibru între faptă şi sancțiuni.

În final, trebuie precizat că studiul realizat de către domnul Tomiță Ciulei (2018, p. 485), intitulat „Analiză comparativă a codurilor de etică din universitățile de top din România”, a relevat faptul că „în sistemul universitar românesc nu există încă o practică unitară în ceea ce privește respectarea normelor de conduită academică...".

Dar mai trebuie menționată și concluzia potrivit căreia „un Cod odată elaborat, devine litera de lege a întregii activități academice, rămânând în vigoare dincolo de legislaturi, de funcții sau momente circumstanțiale date."

\section{Referințe}

Carta, (2012). Carta Universității Dunărea de Jos din Galați, disponibilă la: https://www.ugal.ro/ informatii/documente-publice/carta-universitatii, consultată la data de 27.05.2021.

Ciulei, T.. (2018), Analiză comparativă a codurilor de etică din universităţile de top din România, în Sandu, A. şi Popoveniuc, B., Etică şi integritate în educaţie şi cercetare, Editura Tritonic.

Cod, (2011), Codul de etică şi deontologie profesională universitară al Universității „Dunărea de Jos" din Galați, disponibil la: https://www.ugal.ro/informatii/documente-publice/codulde-etica-si-deontologie-profesionala-universitara, consultat la data de 27.05.2021.

Jeder, D., (2018), Valori etice în discursul educaţional, în Sandu, A. şi Popoveniuc, B., Etică şi integritate în educaţie și cercetare, Editura Tritonic.

Lege, (2011), Legea educației naționale nr. 1. din 2011, M.O. 18 din 10 ianuarie 2011, disponibilă la: http://legislatie.just.ro/Public/DetaliiDocument/125150, consultată la data de 28.05.2021.

Magna Charta Universitatum, 1988, accesibilă la: http://www.magna-charta.org/resources/ files/the-magna-charta/romanian

Mureșan, V., (2009), Managementul etic în organizaţii, Editura Universității din Bucureşti.

Metodologia, (2103), Metodologia de etică şi integritate în procesul de evaluare a universităților din România, Proiect: „Pregătiți pentru a inova, pregătiți pentru a răspunde mai bine nevoilor locale. Calitate și diversitate a universităților din România" - ID POSDRU 123199, 2013, disponibil la pagina http://pe.forhe.ro/sites/default/files/metodologie_etica_ consultare.pdf, consultată la data de 28.05.2021.

Ordin, (2018), Ordinul Ministerului Educației Naționale nr. 3131/2018 privind includerea în planurile de învățământ, pentru toate programele de studii universitare organizate în instituțiile de învățământ superior din sistemul național de învățământ, a cursurilor de etică și integritate academică, M.O. nr. 140 din 14 februarie 2018, disponibil la pagina http://legislatie.just.ro/Public/DetaliiDocumentAfis/197844, consultată la data de 28.05.2021.

Regulament, (2013), Regulamentul de organizare şi funcționare a Comisiei de etică universitară, disponibil la pagina: https://www.ugal.ro/files/site/comisie_etica/Regulament_etica_ brosura_ianuarie_2014.pdf, consultat la data de 28.05.2021.

Regulament, (2017), Regulamentul activității universitare a studenților, disponibil la pagina: https://www.ugal.ro/files/studenti/2019/RAUS_2019_230719.pdf, consultat la data de 28.05.2021.

Ştefan, E.E., (2018), Etică şi integritate academică, Editura Pro Universitaria. 